\title{
Drug patents: innovation v. accessibility
}

$\mathrm{V}$

iews on patent protection for drugs tend to align with opinions on the value of innovation. Brand-name pharmaceutical companies and international trade enthusiasts generally advocate for stronger intellectual property (IP) laws. Without the profits allowed by patent monopolies, they argue, pharmaceutical research and development (R\&D) would stall, depriving patients of new medicines and the economy of new capital.

But generic drug companies and advocates for improved access to affordable medications often take a different view. They tend to argue that brand-name companies abuse the patent system, continually tweaking old molecules to extend monopolies so that prices remain high and profits remain fat.

It should come as no surprise, then, that disputes about drug patents often end up in court. One recently concluded case in India, a seven-year battle between the country's government and Swiss drug maker Novartis, serves as a telling example of just how contentious the world of IP protection can be in the pharmaceutical trade. And because the drug industry is still growing in India, unlike in many in other countries, it will likely be "the epicenter of many battles in the days ahead," according to Intellectual Property Watch, a nonprofit news service.

India has been granting patents for drugs since only 2005 , to comply with the World Trade Organization's TRIPS (Trade-Related Aspects of Intellectual Property Rights) agreement. This agreement was created to bring a degree of uniformity to how IP is protected around the world. That doesn't mean, however, that every nation signing on to TRIPS must agree on which pharmaceutical products deserve patent protection.

"The TRIPS agreement has a lot of flexibility," says Dr. Joel Lexchin, a professor in the School of Health Policy and Management at York University in

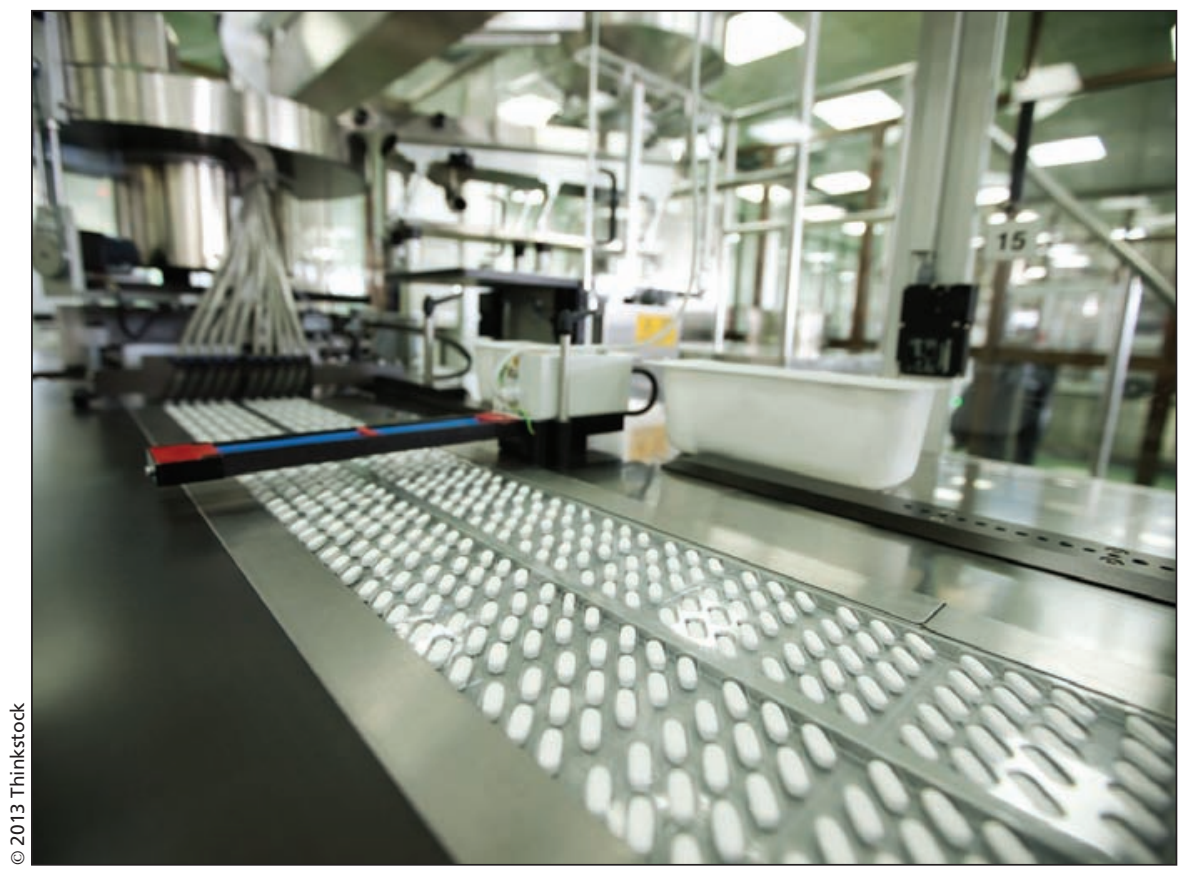

Critics of the intellectual property rights for pharmaceuticals in India claim the country has tailored its patent law to protect its booming generic drug industry.

Toronto, Ontario. "India, as part of its patent law, said if you want to get a patent of a new version of a substance, it has to show significant new therapeutic advantage. That was essentially what the court case depended on."

Indeed, the heart of the legal battle was the question of whether a moreeasily absorbed version of Novartis' lucrative cancer drug Gleevec (imatinib mesylate), known as Glivec in some countries, was enough of an improvement over the original molecule to be considered a new invention. India's Supreme Court decided that it wasn't, based on a section of the country's patent law requiring new versions of old drugs to exhibit enhanced efficacy to earn protection. Critics of the decision claim India's law is far too restrictive and out of step with the rest of the world.

"It is a patent law tailored precisely to the needs of generic companies, allowing them to copy other people's research as quickly as possible," says Paul Herrling, chair of the board of the
Singapore-based Novartis Institute for Tropical Diseases. "Indian generic companies - or the copying industry, as I call them - they make their money by copying stuff that is patented in the rest of the world. Then they sell it cheaper, in India itself or in other countries that don't have strong patent protection."

The lower prices of drugs coming out of India is, in fact, the reason nonprofit groups that work to improve access to medicines in poorer nations are applauding the Novartis decision. "In our opinion, it's a landmark judgment," says Aziz ur Rehman, intellectual property advisor for Médecins Sans Frontières' (MSF) Access Campaign, based in Geneva, Switzerland.

It's not that drug companies don't deserve patents, says ur Rehman, but rather that a balance is needed between protecting the commercial rights of innovators and the rights of the poor to obtain drugs that are inaccessible to them at brand-name prices.

The current IP model of recouping research costs - setting high prices 
until patents expire - is problematic, he says. It provides an incentive for drug companies to invest in products to treat lifestyle diseases that primarily affect richer nations, who can afford to buy them, and to ignore diseases that mostly affect the poor. In poorer nations, suggests ur Rehman, the linkage between IP and high prices simply doesn't work, and pharmaceuticals companies should explore alternative pricing models.

"The companies, instead of making a big fuss when something is happening in a small pharmaceutical market, should be engaged in a more constructive dialogue about what can be done to make more drugs available and affordable, at least in those markets that aren't that lucrative," says ur Rehman.

But according to Herrling at Novartis, patent monopolies are essential to fostering innovation and aren't really hampering access to medications in the developing world. Most of the drugs on the World Health Organization's list of essential medicines, he notes, are already off patent. Furthermore, he says, drug companies such as Novartis have donation programs, and they rarely attempt to enforce patents that are being infringed in impoverished countries.

Yet in IP disputes in poorer countries, suggests Herrling, drug companies are often portrayed in a negative light while nonprofits tend to claim the moral high ground. "It is a very strong psychological argument to say we are defending the poor," he says. "It's a very powerful argument. And the pharmaceutical industry, despite the fact that we keep millions of people out of hospitals and heal them, we have a bad name."

Though focusing on such emotional arguments can win public favour, he says, it might be more productive to focus on the philosophical differences between nonprofits and industry regarding IP protection for drugs. According to Herrling, nonprofit groups often advocate for weakening IP laws to allow immediate access to the latest biomedical innovations.

"However, our view is that, if we did that, it would remove the incentive to do 10 to 15 years of research. The incentive to generate new medicines would go away and that would be to the disadvantage of all patients, rich and poor."

Besides, the truth of the matter is that the decision by India's Supreme
Court was not a social one, but rather about politics and economics, suggests Patrick Kierans, the global head of pharmaceuticals and life sciences for the international law firm Norton Rose, which works in IP, though it did not represent Novartis in the Gleevec dispute. The generic drug business is huge in India, notes Kierans, and it's no surprise that the government wants to protect the wealth and jobs it generates.

"But eventually, India will start having companies with enough money to start innovating, and as soon as they start innovating, they will want to rely on patents to protect their risk. India will change its tune. They will see more value in innovation," says Kierans. "If you look back through history, most periods of great wealth creation came about through innovation. It's like the old adage says, a rising tide lifts all boats." - Roger Collier, CMAJ

\section{CMAJ 2013. DOI:10.1503/cmaj.109-4465}

Editor's note: Part one of a threepart series on pharmaceutical patents in light of the Novartis case in India. 